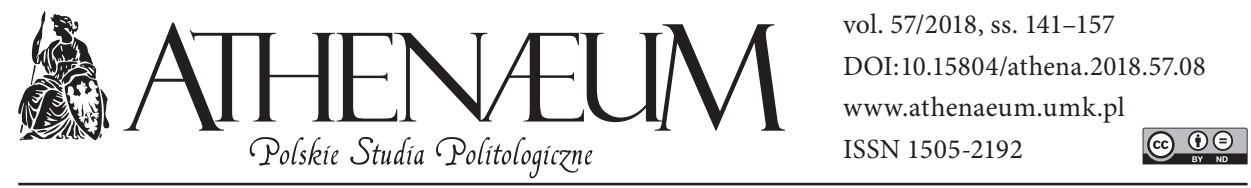

\title{
KRESY WSCHODNIE W BIAŁORUSKIEJ SZKOLNEJ NARRACJI
}

\author{
EASTERN BORDERLANDS \\ IN NARRATION OF THE BELARUSIAN SCHOOL
}

Stanisław Boridczenko*

\begin{abstract}
ABSTRAKT
Problemem podjętym w artykule jest sposób przekazu przez system edukacji szkolnej Republiki Białoruś wiedzy dotyczącej znajdowania się części ziem Białorusi w granicach II Rzeczypospolitej Polskiej. Głównym uzasadnieniem wyboru tematu jest to, iż odpowiednio sformułowany program nauczania może wpływać na kształtowanie świadomości narodowej. Praca oparta jest na oryginalnych wynikach badań materiałów szkolnych używanych w systemie szkolnictwa Republiki Białoruś. W ramach rozprawy został opracowany model teoretyczny przedstawienia kresów w okresie międzywojennym w literaturze szkolnej Białorusi. Znaczącym elementem $w$ badaniu jest uwzględnienie autorskich intencji zawartych w tekście oraz celowo stworzonego przez białoruskich historyków wizerunku Polaków oraz Rzeczpospolitej Polskiej. W wyniku przeprowadzonego opracowania został wyszczególniony charakterystyczny sposób postrzegania przez system białoruskiej edukacji II Rzeczypospolitej Polskiej, a także procesów odbywających się w tym okresie na ziemiach
\end{abstract}

The article considers the issues of teaching history in the school of Belarus thematically related to the Western Belarus in 1921-1939, when that territory was a part of the Second Polish Republic. The main relevance of this article is connected with the importance of the knowledge obtained by the people in school education, which becomes the fundaments of knowledge of the population masses. This work is based on the original results of the study of the school textbooks. All analysed books have a certificate of the Ministry of Education of the Republic of Belarus, which means that they are used in the teaching process in schools. The article presents information about the text of the Belarusian school textbooks and creates theoretical basis related to that theme. The main focus of the article is focused on the study of school texts' intentions and understanding of the terms in which they create an image of the Polish nation and an image of the Polish Republic. The result of the work is presented as detailed characteristic of ways in which Belarusian school precipitates time period between 1921-1939. Also, it has

* Uniwersytet Szczeciński, Wydział Humanistyczny. 
Zachodniej Białorusi. W rozprawie przyjęto tezę, zgodnie z którą Republika Białoruś w podręcznikach dla uczniów stwarza obraz wroga zewnętrznego, którego rolę w jej przypadku pełni Polska oraz Polacy.

Słowa kluczowe: Białoruś, historia, II Rzeczpospolita Polska characteristics of the description of the processes accompanying the Western Belarus lands under the Second Polish Republic rule.

Keywords: Belarus, history, Second Polish Republic

\section{WPROWADZENIE}

W ciągu wieków kształt granic Rzeczypospolitej Polskiej się zmieniał. Przykładowo w obręb II Rzeczypospolitej Polskiej wchodziły między innymi tereny, które dziś są niezależnymi państwami. Nazwane jeszcze w XX wieku Kresami Wschodnimi skupiały one na swym obszarze ludność czterech narodów: Polaków, Białorusinów, Litwinów i Ukraińców. Współistnienie etnicznie różnorodnej ludności na Kresach nie zawsze było bezkonfliktowe. W wyniku trwałych procesów o charakterze polityczno-historycznym niektóre z byłych wschodnich województw II Rzeczypospolitej stały się częścią innych państw (Białorusi, Litwy oraz Ukrainy; Nowak, 2011).

W artykule zdecydowano się omówić sposób postrzegania Rzeczypospolitej Polskiej przez jeden z krajów, który wcześniej stanowił częściowo terytorium II Rzeczypospolitej Polskiej. Mianowicie w poniższej pracy przedstawiono sposób rozumienia Polski oraz Polaków w okresie międzywojennym przez obecny system edukacji Republiki Białoruś. Zakres tematyczny analizy wymusił przeprowadzenie szeroko zakrojonej kwerendy wśród prac naukowych w języku polskim i rosyjskim. Już na początku zauważono niedostatek prac na wyznaczony temat, w języku zarówno polskim, jak rosyjskim, wskutek czego artykuł będzie się opierał na własnym opracowaniu źródeł, czyli materiałów szkolnych z Republiki Białoruś. Jednocześnie warto zaznaczyć, iż badana problematyka (polityka historyczna Republiki Białoruś w kontekście treści podręczników historycznych) została częściowo omówiona w pracach Zdzisława Winnickiego Historiografia jako metoda kształtowania współczesnej białoruskiej świadomości narodowej Współczesna doktryna i historiografia białoruska (po roku 1989) wobec Polski i polskości. Także powiązania polityki historycznej z treścią literatury szkolnej na Białorusi są badane przez Teresę Maresz. Najbardziej istotną pracą z punktu widzenia poniższego artykułu jest: Podręcznik szkolny narzędziem kształtowania 
świadomości historycznej młodzieży. Analiza porównawcza polskich, rosyjskich, białoruskich i ukraińskich podręczników do historii z przełomu XX i XXI wieku.

Zagadnieniem zasadniczym w relacjach ze wschodem jest kwestia następująca: w jaki sposób obywatele tych państw postrzegają Polaków oraz Rzeczpospolitą Polską przez pryzmat historii? Jest to temat rozległy, gdyż powiązany z takimi pojęciami jak polityka historyczna i pamięć narodowa. W następstwie tego na potrzeby artykułu skupiono się jedynie na badaniu zawartego w materiałach szkolnych opisu okresu międzywojennego (II Rzeczypospolitej Polskiej). Możliwe jest prowadzenie rozmaitych dyskusji, lecz najlepszym źródłem, z którego da się wyciągnąć wnioski o nastrojach wśród społeczeństwa, są podręczniki szkolne. Podobne twierdzenie uzasadniono tym, iż ważne miejsce w budowaniu światopoglądów ludzi zajmuje kształcenie na poziomie szkolnym, dlatego że młode umysły są podatne na przyjmowanie wzorców; a w młodym wieku szkoła jest niejako autorytetem, więc przedstawione w niej informacje nie podlegają zakwestionowaniu (Maresz, 2017). Do tego także warto dodać to, że w państwach podobnych do Białorusi (czyli państwach $\mathrm{z}$ autorytarnymi postsowieckimi reżimami) tezy zawarte w podręcznikach posiadają charakter formalny, bowiem stanowią wyraz wizji władz odnośnie historii.

Podstawowym celem niniejszej pracy jest analiza tekstów literatury szkolnej Republiki Białoruś oraz opis tego, w jaki sposób uczniom w tym państwie przekazywano wiedzę dotyczącą ziem białoruskich znajdujących się niegdyś w granicach II Rzeczypospolitej Polskiej. Stawiana w artykule teza zakłada, iż jak każde państwo „młode” Republika Białoruś próbuje stworzyć obraz nieprzyjaciela z zewnątrz, który w jej przypadku pełni Rzeczpospolita Polska. Spowodowane jest to długotrwałą agitacją Związku Radzieckiego przeciwko Polsce w społeczeństwie białoruskim.

Niniejszy temat wymaga szczególnego wyjaśnienia zastosowanej terminologii. Niewątpliwie między historykami różnych państw nadal toczy się debata o badanym okresie, niemniej jednak spory te nie mają charakteru konstytutywnego - innymi słowy nie zmieniają faktologii. Głównym pojęciem podpadającym pod analizę są „kresy wschodnie”, które stanowią wschodnie pogranicze II Rzeczpospolitej Polskiej (trzeba zaznaczyć, iż uwaga artykułu skupiona jest jedynie na kresach zamieszkanych przez Białorusinów, w taki sposób w ramach niniejszego artykułu „Kresy” równają się terenom byłych województw: wileńskiego, białostockiego, nowogrodzkiego oraz poleskiego; Śleszyński, 2013). Obecnie w Republice Białoruś na tych ziemiach stworzono trzy administracyjno-terytorialne jednostki (obwody): brzeski, grodzieński oraz częściowo miński (Koprowski, 
2006). Nie zagłębiając się w sprawy historyczne, trzeba zaznaczyć, iż w ciągu wieków obszar ten należał do różnych państw: zaczynając od Rusi Kijowskiej i kończąc na obecnym znajdowaniu w składzie Republiki Białoruś (Szybieka, 2002). Zostawiło to swoje piętno także na ludności ją zamieszkującej, gdyż nie była (i wciąż nie jest) ona etnicznie jednorodną. Zgodnie $\mathrm{z}$ wynikami spisu ludności, od 1921 roku Białorusini stanowili 37,7\% populacji w województwie Nowogrodzkim, 42,6\% w województwie Poleskim, 9,1\% w województwie białostockim i 25,7\% w województwie wileńskim (Kubiczek, 1994). Dominującym wyznaniem tej ludności było prawosławie i zamieszkiwała ona przeważnie tereny wiejskie (Sahanowicz, 2001).

W granicach II Rzeczypospolitej Polskiej Kresy znalazły się w wyniku podpisania traktatu pokojowego (ryskiego) z nowo powstałym spadkobiercą Imperium Rosyjskiego - ZSRR. Na podstawie wspomnianego traktatu teren dzisiejszej Białorusi został podzielony pomiędzy dwa państwa: II Rzeczpospolitą Polską i ZSRR. Oba kraje rozpoczęły prowadzenie własnej polityki na tym obszarze, która w Związku Radzieckim skutkowała nadaniem Białorusinom państwowości (BSRR). Natomiast władze polskie na tych terenach utworzyły województwa, na terenie których Białorusini nie posiadali dodatkowych przywilejów (Szybieka, 2002). Obecnie oficjalna szkoła historyczna Republiki Białoruś uznaje BSRR za pierwsze państwo białoruskie (Winnicki, 2006), jednocześnie określając tereny pod jurysdykcją Warszawy (w okresie międzywojennym) za okupowane. W przeprowadzanej przez Białoruś polityce historycznej tkwi przyczyna istotnego konfliktu między szkołami historycznymi Polski a Białorusi, gdyż zakwestionowaniu - ze strony białoruskich historyków - podlegają nawet wyniki spisów ludności z lat międzywojennych. Natomiast w szkole historycznej Rzeczypospolitej Polskiej ustanowienie jurysdykcji Warszawy nad nowo stworzonymi województwami: nowogrodzkim, poleskim oraz wileńskim (w którym odsetek Białorusinów był o wiele mniejszy) jest rozpatrywane z nieco innej pozycji, gdyż uzasadniano to historyczno-etniczną zależnością tych ziem od Polski (Śleszyński, 2013).

Warty uwagi jest fakt, iż etnogeneza Białorusinów jako narodu trwała w ciągu całego okresu międzywojennego, co z kolei w sposób bezpośredni wpływa na koncepcje opracowywane przez historyków różnych państw. Przykładowo opis struktury społecznej Kresów znacznie się różni w źródłach polsko- i rosyjskojęzycznych. Podobne rozróżnienia dotyczą również nastawienia do polityki władz polskich wobec ludności białoruskiej (Koprowski, 2006). 
Ponieważ podstawowym celem tego artykułu jest analiza tekstów literatury szkolnej Republiki Białoruś, istotny jest system edukacji w tym państwie. Jak w większości innych krajów postsowieckich, na Białorusi ukształtował się jednolity system szkolnej edukacji, która trwa jedenaście albo dziewięć lat w zależności od preferencji ucznia. Do szkoły idzie się w 6, 7 lub 8 roku życia. Wykształcenie średnie zdobywa się po ukończeniu XI klasy, zaś zaliczenie IX klasy oznacza zdobycie wykształcenia bazowego. Niewątpliwym odróżnieniem systemu edukacji Republiki Białoruś od reszty poradzieckich krajów jest jednolity podręcznik z historii (czyli jedyna obowiązkowa wersja dla wszystkich placówek edukacyjnych). Dlatego analiza wybranego zagadnienia była o tyle uproszczona, iż podstawą badania stała się jedna książka: podręcznik do historii dla klasy dziesiątej zaakceptowany przez Ministerstwo Edukacji Republiki Białoruś, którym posługiwano się we wszystkich szkołach tego państwa. Książka ta nosi tytuł Historia Białorusi w latach 1917-1945 i została napisana przez białoruskiego historyka Eugenia Nowika. W celu pogłębienia wiedzy na oznaczony temat skorzystano z dodatkowych źródeł, między innymi: podręczników $\mathrm{z}$ poprzednich lat (którymi obecnie $\mathrm{w}$ trakcie zajęć się nie posługiwano) oraz zalecanych przez Ministerstwo Edukacji materiałów pozaszkolnych. Jednak stały się one tylko uzupełnieniem, bowiem pierwotnym celem artykułu jest ujawnienie obecnie prezentowanego w literaturze szkolnej Republiki Białoruś obrazu II Rzeczypospolitej Polskiej. Trzeba od razu zaznaczyć, iż na Białorusi uczniowie spotykają się z wyznaczonym tematem jeden raz na cały tok szkoły, aż do klasy $\mathrm{X}$. W starszych rocznikach zagadnień związanych z kresami II Rzeczpospolitej nie poruszano, gdyż nauczenie historii odbywa się na chronologicznej zasadzie: w klasie VI (kiedy rozpoczynają się obowiązkowe zajęcia $\mathrm{z}$ historii) nauczano historii starożytnej, w klasie VII - historii średniowiecza, w klasie VIII historii wieków XVI - XVIII, w klasie IX - historii XVIII w. i początku XX w., i w ostatniej klasie (XI) dzieci dowiadują się o dziejach z drugiej połowy XX - początku XXI w.

Wspomniana Historia Białorusi w latach 1917-1945 obecnie stanowi jedyny podręcznik z historii dla klas X dopuszczony do szkół na Białorusi. Jak wynika z nazwy, obejmuje okres od upadku Imperium Rosyjskiego do zakończenia II wojny światowej. Uwaga tekstu skupiona jest na opisie procesów historycznych na ziemiach białoruskich - przynajmniej tak wynika z adnotacji. Książka podzielona jest na rozdziały na zasadzie chronologicznej. Każdy rozdział kończy się zestawem krótkich zagadnień skierowanych do ucznia oraz ogólnym pytaniem na temat poruszanej epoki. Także w podręczniku zamieszczone są wypisy źró- 
dłowe, zdjęcia i mapy. W zakończeniu poszczególnych paragrafów znajduje się spis terminów i dat, które uczeń powinien znać na pamięć.

Pozaszkolne materiały (także znane jako podręczniki uzupełniające), których treść została zanalizowana w pracy, różnią się obudową, lecz zawarte w nich koncepcje są zbieżne. Przyczyną podobieństwa tekstów białoruskiej literatury dla uczniów są ograniczenia Ministerstwa Edukacji oraz to, że są one pisane przez nieliczne grono historyków (przykładowo większość zbadanych tekstów została napisana przez Eugenia Nowikia i Sergeja Panowego).

\section{RZECZPOSPOLITA POLSKA W MATERIAŁACH EDUKACYJNYCH REPUBLIKI BIAŁORUŚ}

Ze wspomnieniami o Polsce białoruscy uczniowie spotykają się w ciągu całego kursu historii szkolnej, gdyż trudno omawiać historię Białorusi, nie wspominając Polaków, którzy przez wieki zamieszkiwali tereny na wschodzie (znane dziś w historiografii jako Kresy Wschodnie; Koprowski, 2006). Jednocześnie warto podkreślić, że opis polskiej problematyki kończy się jedynie krótkimi wzmiankami o Polakach, bez prób szerszego opisu historii narodu polskiego czy odrębnego przekazu wiedzy dotyczącej dziejów polskiej mniejszości na Białorusi. Przykład podobnej obojętności tekstów wobec postępowań Polaków stanowią materiały z historii Białorusi dla klasy dziesiątej, gdyż zawierają one temat znajdowania się części białoruskich obecnie terenów w granicach II Rzeczypospolitej Polskiej. Niewątpliwie w innych klasach też sięgano po opis Polaków oraz Polski, niemniej jednak przekazywano w nich wiedzę z wcześniejszego okresu (XVI-XVIII wieku), która znajduje się poza ramami zainteresowań danego artykułu.

Nawet po pobieżnym zapoznaniu się z treścią literatury szkolnej używanej w Republice Białoruś da się wyprowadzić wniosek, że stanowisko autorów nie jest przychylne Rzeczypospolitej Polskiej. Białoruskie podręczniki do historii prezentują przeważnie negatywny sposób opisu Polaków oraz Polski, gdyż podnoszą wiele kontrowersyjnych momentów z historii, naświetlając je w sposób niekorzystny dla Polaków. Co więcej, treść materiałów w sposób prosty wskazuje na to, iż w ciągu wieków Białoruś była uznawana przez Polaków za kolonię, a białoruski naród był uważany za „ludność gorszego rodzaju” (Puryszewa, Starowojtowa, 2008). Trzeba zaznaczyć, że negatywne nastawienie tekstów do państwa polskiego czasami zmienia się na łagodniejsze. Podobna odmienność zależy od tego, do jakiego przedmiotu należy badany materiał (w systemie bia- 
łoruskiej oświaty jednocześnie istnieją takie przedmioty, jak Historia Białorusi i Historia Powszechna) oraz tego, jaki historyczny etap ukazywano. Niemniej jednak ze względu na to, że niniejszy artykuł ma na celu badanie wiedzy o ściśle określonym okresie, w jego ramach uzasadnione będzie twierdzenie o krytycznym nastawieniu autorów w stosunku do II Rzeczypospolitej Polskiej.

W dziesiątym roku uczęszczania do szkoły, zgodnie z oficjalnym planem zajęć zaakceptowanym przez Ministerstwo Edukacji Republiki Białoruś, uczniowie powinni mieć zajęcia obejmujące przekaz wiedzy z okresu międzywojennego na Kresach. Jak już wspomniano powyżej, na Białorusi są dwa przedmioty, które odnoszą się do badanego wątku: przedmiot pierwszy występuje pod nazwą Historia Białorusi (Istorija Biełarusi); drugim jest Historia Powszechna (Wsiemirnaja Istorija; Uczebnyje programmy dla uczrieżdienij obszczego sriedniegoobrazowanija s russkim jazykom obuczenija. Wsiemirnaja istorija. Istorija Biełarusi V-XI kłassy, 2014).

W treści książki do historii powszechnej nie udało się odnaleźć żadnych ogólnych charakterystyk II Rzeczypospolitej Polskiej, zwłaszcza pod kątem Kresów Wschodnich. W materiałach kierowanych do tego przedmiotu wspomnienia o Polsce pojawiają się na zasadzie jej opisu jako tła w rozważaniach o polityce zewnętrznej ZSRR i hitlerowskich Niemiec. Natomiast treść podręcznika do historii Białorusi zawiera względnie obszerny tekst o badanej problematyce, który mieści się w rozdziale Białoruś w warunkach genezy sowieckiego socjalistycznego społeczeństwa. Białoruś Zachodnia pod władzą Polski. Składa się on z dwóch podrozdziałów znajdujących się w ramach zainteresowania danego artykułu. Podrozdział pierwszy to Białoruś Zachodnia pod władzą Polski, w którym są opisywane zagadnienia związane $\mathrm{z}$ warunkami politycznego oraz gospodarczego egzystowania Białorusinów na Kresach. Podrozdział drugi dokonuje analizy kultury narodu białoruskiego w obrębie II Rzeczypospolitej Polskiej. Ta część jest zatytułowana: Stan kultury na Białorusi Zachodniej. Obydwa wymienione paragrafy liczą razem 9 stron (natomiast cała książka zawiera 182 strony). Prócz wymienionych powyżej wątków wspomina się o tym, iż szereg terenów obecnej Republiki Białoruś znajdowała się pod jurysdykcją Warszawy, co można odnaleźć i w innych częściach tego samego podręcznika. Jednakowoż stanowią one epizodyczne uwagi i nie tworzą żadnej całości. Podobne luki są zauważalne w pozaszkolnej literaturze, przykładowo w Historii Białorusi. Dla VI-XI klas. Pozycja ta, rekomendowana uczniom dla pogłębiania wiedzy przez ministerstwo edukacji Republiki Białoruś, zawiera główne daty i zdarzenia z komentarzami, brakuje w niej jednak wątków związanych z latami 20.-30. W równej mierze 
dotyczy to reszty pozaszkolnych materiałów edukacyjnych (Historii Białorusi w XVIII-XX wieku autorstwa Witalia Sosno, Historii Białorusi. Krótki kurs szkolny autorstwa Nikołaja Puryszewa i Nadieżdy Starowojtewej itd.).

Ze względu na ścisłe powiązanie w białoruskiej literaturze szkolnej przekazu wiedzy o stanie rzeczy na Kresach w latach 1921-1939 z etapem poprzednim, warto też krótko omówić to, w jaki sposób uczniom prezentowano zdarzenia przypadające na czasy odzyskania przez Polskę niepodległości po 123 latach rozbiorów. Temat ten $\mathrm{z}$ reguły znajduje się w rozdziale wcześniejszym od opisującego okres II Rzeczypospolitej Polskiej; analiza tego wątku pomoże w stworzeniu pełnego obrazu treści odnoszącej się do Kresów w granicach II Rzeczypospolitej Polskiej. Twierdzenie o zwartości przekazu dwóch epizodów historycznych polega na tym, iż w obecnie obowiązującym podręczniku na samym początku rozdziału zatytułowanego: Białoruś w warunkach genezy sowieckiego socjalistycznego społeczeństwa. Białoruś Zachodnia pod władza Polski, autor zadaje uczniom pytanie, które nawiązuje do czasów wojny polsko-bolszewickiej. Zagadnienie brzmi: „Czym skończyła się wojna domowa i obca interwencja dla Białorusi?" (Nowik, 2012). W danym przypadku istotne jest użycie terminu „obca interwencja”, gdyż, jak wiadomo z historii, odbywała się ona na terenach innych niż Białoruś (miała miejsce na Dalekim Wschodzie, rosyjskiej północy oraz częściowo na Krymie i Kaukazie). Natomiast istotną rolę w białoruskiej historii odegrała wojna pomiędzy bolszewikami a Polską, jednak autor stara się ominąć ten moment, przynajmniej w wątku związanym z Białorusią Zachodnią pod rządami II Rzeczypospolitej Polskiej. Jest to bardzo istotna informacja, gdyż od razu wskazuje na dążenie historiografii do pomięcia zagadnień związanych z polską problematyką i skupienia uwagi na dziejach Rosji (zastąpienie wojny polsko-bolszewickiej interwencją państw zachodnich).

Autorzy białoruskich materiałów podkreślają, iż znajdowanie się ziem białoruskich pod zwierzchnictwem rządu w Warszawie stało się skutkiem polskiej agresji, wynikającej z planów po odbudowie Rzeczypospolitej Obojga Narodów, (Nowik, 2009). W książkach do historii w sposób prosty wskazywano, iż elita nowo powstałego państwa polskiego (II Rzeczypospolitej Polskiej) dążyła do aneksji terenów leżących na wschód od etnicznych polskich ziem i te dążenia wyszły na jaw zaraz po uzyskaniu niepodległości od Rosji (Treszczenko, 2009). „Rząd polski wybrał swoim celem odbudowę Rzeczypospolitej Obojga Narodów w granicach z 1772 r., z włączeniem w skład Polski Litwy oraz obszernych terenów Ukrainy i Białorusi” (Nowik, 2012). W podobny sposób ten sam moment jest opisany w literaturze pozaszkolnej, w której nawet użyto terminu: „ludobójstwo” 
i „niczym nie spowodowana agresja” w stosunku do czynów II Rzeczypospolitej na Białorusi (Panow, 2016). Jak wynika $z$ intencji powyższego cytatu, białoruscy historycy piszący podręczniki nie mają żadnej wątpliwości przy określeniu podstaw polskiej polityki w latach 1918-1922. Podobne nastawienie do istoty procesów, które odbywały się na arenie międzynarodowej po zakończeniu I wojny światowej, przekłada się na uznanie faktu znalezienia się części ziem dzisiejszej Białorusi pod okupacją Polaków (Panów, 2013). Termin „okupacja” w kontekście II Rzeczypospolitej w obowiązującym podręczniku użyto 6 razy (Nowik, 2012). W testach rekomendowanych dla sprawdzania wiedzy uczniów X klasy (autorstwa Siergieja Panowa oraz Siergieja Ratko) Kresy są uznane za okupowane ziemie zachodniobiałoruskie. W podręcznikach już nieobowiązujących też są wzmianki o okupacyjnym charakterze władzy Polski nad Kresami (Nowik, 2009). Nieco odmienną jest interpretacja tych dziejów dokonana jednak z udziałem Rosjan. W literaturze szkolnej zakładano, iż komuniści przynieśli wolność narodowi białoruskiemu, dbając o jego kulturę oraz suwerenność (Nowik, 2012); co więcej, dany wątek nie podlega zakwestionowaniu nawet w materiałach pozaszkolnych. Wyżej wymienione fakty wskazują, iż w systemie edukacji Republiki Białoruś kreowano obraz II Rzeczypospolitej Polskiej jako okupanta ziem zachodnio-białoruskich. Natomiast wejście terenów Białorusi do kształtującego się na początku lat 20. Związku Radzieckiego uznano za akt dobrej woli. Podobna rozbieżność w definicji jednego procesu (lecz odbywającego się z uczestnictwem różnych aktorów) najlepiej uwypukla historyczne narracje oficjalnej szkoły Republiki Białoruś.

Całość materiału o Kresach w latach międzywojennych napisana jest w sposób niekorzystny dla wizerunku narodu polskiego. Przykładowo, w obecnie obowiązującym podręczniku już w pierwszym akapicie uczniowie czytają, iż „władze polskie nie uznały terminu «Białoruś Zachodnia» w wyniku czego w dokumentach oficjalnych w stosunku do Białorusi Zachodniej wykorzystywano określenie «kresów wschodnich»" [w tekście zamiast rosyjskiego odpowiednika słowa „kresy” użyto transkrypcji polskiego słowa w cyrylicę] (Nowik, 2012). Należy zaznaczyć, że na Białorusi termin „kresy” jest postrzegany nieco inaczej niż w historiografii polskiej i ma znaczenie wyraźnie negatywne, co po raz kolejny udowodnia, że białoruscy historycy nie mają ograniczeń w przekazie negatywnych cech II Rzeczypospolitej Polskiej. Fakty prezentujące Polskę w negatywny sposób w białoruskich materiałach dla uczniów mogą być tak samo realne, jak wymyślone, zaś polemika o poprawności nie należy do celów tego artykułu. Kontynuacją słów o rezygnacji II Rzeczypospolitej Polskiej z terminu „Białoruś 
Zachodnia" stanowi sprawozdanie o tym, iż Białoruś sprowadzono do roli surowcowej kolonii rdzennych polskich ziem. „Białoruś Zachodnia stała się agrarnym dodatkiem przemysłowych rejonów Polski, rynkiem zbytu i źródłem taniej siły roboczej" [w podręczniku zdanie zostało wyróżnione kursywą przez autora] (Nowik, 2012). Podobna teza zawarta jest nie tylko w obecnie obowiązującym podręczniku, lecz w podręcznikach z lat 90. oraz wydanych za czasów BSRR (udowodnia to co najmniej częściowe przejęcie paradygmatów opracowanych przez historyków ZSRR przez szkołę historyczną Republiki Białoruś). Podobny opis uzupełniany jest także twierdzeniem o celowym pogorszeniu warunków życia w województwach zamieszkanych przez Białorusinów (poleskim, nowogrodzkim, wileńskim i białostockim; Panow, 2014). W materiałach edukacyjnych białoruscy historycy ukazują, iż wysokość pensji - tak samo jak długość czasu pracy - różniła się w zależności od tego, czy jednostka administracyjna należała do rdzennych ziem polskich. „Długość czasu pracy sięgała 10-12 godzin, pensje robotników były mniejsze niż na rdzennych polskich ziemiach" (Nowik, 2012). Pozycja autorów nie zakłada możliwości uwzględniania informacji alternatywnych, gdyż nawet materiały pozaszkolne pisane są na tej samej zasadzie co obowiązujący podręcznik. W wyniku tego uczniowie nie zdobywają wiedzy o tym, że stopień rozwoju różnych województw w II Rzeczypospolitej Polskiej od samego początku różnił się, co skutkowało wyprzedzaniem kresów przez ziemie zachodnie; co więcej, ta nierówność spowodowana była nie celową polityką Warszawy, lecz trwałym okresem znajdowania się ziem białoruskich pod bezpośrednią władzą Imperium Rosyjskiego (Szybieka, 2002). W danym wątku, jak w wielu innych, ujawniono uczniom jedynie część prawdy, co powoduje naświetlenie dziejów historycznych w sposób korzystny dla białoruskiej elicie rządzącej.

Bezspornie materiały opisujące stan rzeczy na kresach zamieszkanych przez Białorusinów kładą nacisk na przekaz informacji o presji okazywanej na Białorusinach przez władze II Rzeczypospolitej Polskiej. Wiedza zawarta w szkolnej literaturze zaciera granice między Polakami jako narodem a państwem polskim. Uczniom przekazuje się, że Polacy w okresie międzywojennym stali się kolonistami we wschodnich województwach II Rzeczypospolitej Polskiej, prowadzącymi politykę polonizacji tego terytorium (Nowik, 2012). Między innymi autorzy literatury w sposób negatywny postrzegają przesiedlenie Polaków na wschód po wojnie polsko-bolszewickiej, podkreślając, że podobne przemieszczenie ludności stało się odzwierciedleniem dążenia rządu polskiego do pacyfikacji obszarów okupowanej Białorusi (Panow, 2017). Ttakie stanowisko jest oficjalne i zawarte 
w materiałach pozaszkolnych oraz testach maturalnych z historii. Przykładowo w zbiorze zagadnień maturalnych autorstwa Siergieja Panowa Polaków na Wschodzie określano kolonistami (w negatywnym znaczeniu tego słowa), co więcej, wspominano o polityce „pacyfikacji”, która na Białorusi jest synonimem ludobójstwa. W obowiązującym podręczniku ten wątek jest opisany w sposób następujący: „W geście wdzięczności po wojnie 1919-1920 rząd polski rozdał zachodnio-białoruskie ziemie byłym oficerom i urzędnikom. Nowych kolonistów nazywano osadnikami. Ludzie ci byli dobrze zorganizowani, uzbrojeni i pełnili funkcje policyjne w stosunku do ludności tutejszej. Razem na tereny Zachodniej Białorusi przesiedlono około 10000 osadników" (Nowik, 2012). Podany cytat zaznacza, iż polscy osadnicy pełnili funkcje policyjne, dlatego posiadali broń. Ważne znaczenie posiada użycie terminu „koloniści”, gdyż w sposób jaskrawy wskazuje na próbę oczernienia Polaków, którzy przenieśli się na wschód w latach 1921-1939. Ponadto w tekście zignorowano fakt, iż na Kresach osiedlali się przeważnie demobilizowani żołnierze - uczestnicy wojny z bolszewikami, w posiadanie którym przyznano ziemie wcześniej należące do skarbu rosyjskiego oraz do członków byłej dynastii Romanowów, w wyniku czego ludność białoruska nie ucierpiała materialnie (Sowa, Brzoza, 2006).

Warto zaznaczyć, że w obowiązującym podręczniku (a także w materiałach pozaszkolnych zaakceptowanych przez Ministerstwo Edukacji) prawie nie podnoszono kwestii, że ludność polska stanowiła znaczny odsetek mieszkańców Kresów (od 76,8\% w województwie białostockim, do 24,3\% w województwie poleskim; Kubiczek, 1994) i była społecznością rdzenną, zamieszkującą tereny te od setek lat. Przeciwnie, historycy usiłują udowodnić tezę, zgodnie z którą Polacy byli mniejszością przybyłą, próbującą asymilować się w narodzie białoruskim (Treszczenko, 2009). Przykładowo, w przekazie o sytuacji demograficznej na Kresach uczniów informowano o fałszerstwie oficjalnych statystyk z II Rzeczypospolitej Polskiej, według których Polacy stanowili znaczny odsetek populacji. W zbadanych tekstach wskazywano, iż jako Polaków w spisach ludności zapisywano Białorusinów wyznania katolickiego oraz część Białorusinów prawosławnych. Przykładowo obecny podręcznik do historii zawiera informacje o tym, że w województwach wileńskim oraz poleskim ilość Polaków była zawyżona z 12\%-13\% do 42\%, jednocześnie procent osób pochodzenia białoruskiego w sposób sztuczny został zmniejszony z 67\% do 22,5\%. „Dane statystyczne o narodowym podziale ludności Białorusi Zachodniej fałszowano, gdyż jako Polaków zapisywano prawie wszystkich Białorusinów katolików i wielu prawosławnych"(Nowik, 2012). Przykład ten unaocznia kierunek polityki historycznej 
Republiki Białoruś, który dąży do zacierania śladów polskich w historii kraju. Także ciekawym momentem jest wspomnienie w podręczniku o województwie wileńskim jako o terenie zamieszkanym przeważnie przez Białorusinów i stanowiącym część historycznych ziem białoruskich. Podobnych wzmianek o Wileńszczyźnie w materiałach pozaszkolnych nie udało się odczytać.

Białoruska literatura szkolna wskazuje na zamiary Rzeczypospolitej Polskiej docelowego likwidowania narodu białoruskiego przez jego „opolaczywanie” (polonizację); we wszystkich zbadanych białoruskich materiałach edukacyjnych użyte są te same argumenty udowodniające podobne twierdzenie. Po pierwsze, zaznaczano oficjalną rezygnację Warszawy przed uznaniem Białorusinów za naród. „Władze polskie nie uznały narodu białoruskiego i próbowały walczyć ze świadomością narodową przez opolaczywanie" (Nowik, 2012). Po drugie, w tekście zaakcentowano, iż za czasów „okupacji” kresów przez rząd polski zostały zlikwidowane wszystkie białoruskojęzyczne ośrodki edukacyjne. „W roku edukacyjnym 1938/39 na Białorusi Zachodniej nie ostał się żaden białoruski ośrodek edukacyjny" (Nowik, 2012). Podobne informacje są powtarzane w materiałach pozaszkolnych, przykładowo w: Istorija Biełarusi. Posobije dla podgotowki k centralizowannomu tiestirowaniju, która ma za zadanie przygotowanie uczniów do zdania egzaminu maturalnego $\mathrm{z}$ historii. $\mathrm{W}$ celu ubarwienia podobnych informacji w obecnie obowiązującym podręczniku (a także $\mathrm{w}$ jego poprzednich wersjach) uwzględniono dane, zgodnie z którymi znaczna ilość obywateli ze wschodnich województw II Rzeczypospolitej Polskiej była analfabetami. „Około 13\% dzieci w wieku szkolnym nie uczęszczało do szkół, 43\% społeczeństwa $\mathrm{w}$ wieku ponad 10 lat było analfabetami. Inteligencji pochodzenia białoruskiego prawie nie było" (Nowik, 2012). Jak wynika z tekstu, było to skutkiem polityki Warszawy, która polegała na ignorowaniu potrzeb narodu białoruskiego oraz na ograniczeniu jego dostępu do edukacji, skutkiem czego nastąpiło pozbawienie Białorusinów tożsamości narodowej.

Na podstawie powyższego można wyprowadzić wniosek, iż opis genezy narodu białoruskiego na kresach w II Rzeczypospolitej Polskiej w szkołach Białorusi polega na opowiadaniu o „trudności” tego etapu dla kultury zachodniobiałoruskiej, która okazała się elementem polityki wrogiego państwa. Odbywa się to także na podstawie stworzenia wizerunku Białorusinów jako strony cierpiącej od okupantów (Polaków). Niemniej jednak nieskuteczność narracji tkwi w samej treści materiałów szkolnych, gdyż sprzeczne momenty są łatwo odnajdywane nawet przy pobieżnym zapoznaniu się z tekstami. Przykładowo jeden z czołowych historyków Republiki Białoruś - Eugenij 
Nowik, który napisał aktualnie obowiązujący podręcznik, twierdzi, iż jednym z rezultatów opresyjnej polityki władz polskich stało się prześladowanie działaczy kultury białoruskiej. Prześladowania te polegały na zamknięciu wszystkich białoruskojęzycznych ośrodków kulturalnych, aresztowaniu i wyrokach sądowych dla publicystów piszących po białorusku, ale w tymże samym tekście podręcznika umieszczano informacje o rozmaitych stowarzyszeniach Białorusinów, które działały w latach 1921-1939. Działalność białoruskich organizacji w podręczniku naświetlano tylko na podstawie zarysu trudności, z którymi się one spotykały. Podobne nastawienie do opisu historii nie dotyczy jedynie tych stowarzyszeń, lecz całego okresu historii. Nie może to wytrzymać żadnej krytyki naukowej, gdyż podobne nastawienie jest stronnicze, nie ma nic wspólnego z historią jako nauką. Niewątpliwie literatura szkolna w Republice Białoruś posiada charakter propagandowy i ma na celu dopasowywanie opisu dziejów historycznych do potrzeb reżimu.

\section{SPOSÓB PRZEDSTAWIANIA POSTACI HISTORYCZNYCH}

Istotną część analizy, która uwzględnia politykę historyczną Republiki Białoruś na przykładzie opisu II Rzeczypospolitej Polskiej, stanowi badanie treści materiałów pod kątem narodowości wymienianych w nim nazwisk. Nie ma wątpliwości, iż pod tym względem najliczniejszą grupę stanowią działacze pochodzenia białoruskiego, którzy prowadzili działalność na Kresach w okresie międzywojennym. Zauważalne jest to, że osoby te są podzielone, na elitę intelektualną oraz na aktywistów politycznych; co ważne, przy opisie działalności tych osób, głównie skupiano uwagę na walce toczonej przez nich przeciwko Polakom oraz II Rzeczypospolitej Polskiej (Nowik, 2012). Odnosi się to zarówno do inteligencji, jak i do aktywistów politycznych. Na istotność antypolskiej narracji wskazuje wybór ujawnianych nazwisk. Przykładowo wśród wielu powszechnie nieznanych nawet na Białorusi publicystów został wyszczególniony Michał Wasilek, znany przeważnie dzięki swemu antypolskiemu stanowisku. Jako przykład jego twórczości autor obowiązującego na Białorusi podręcznika wskazuje na wiersze: Jak przetrwałem pana oraz Do boju z okupantami. W wyjaśnieniach do tych utworów stwierdzono, że napisane były one z zamiarem wsparcia białoruskiego ruchu narodowo-wyzwoleńczego $\mathrm{z}$ „polskimi panami”. W danym przypadku z intencji tekstu wynika, iż za polskich panów postrzegano wszystkie osoby o pochodzeniu polskim. Niewątpliwie podobne wzmianki - które łatwo odnaleźć 
nie tylko w obecnie obowiązującym podręczniku do historii, ale i w materiałach pozaszkolnych - promują twórczość pisarzy $\mathrm{z}$ antypolskimi poglądami.

Inną grupę działaczy historycznych, do których sięgają autorzy literatury dla uczniów, stanowią aktywiści polityczni (w swej masie powiązani z partią komunistyczną). Przy wymianie ich nazwisk wskazywano, iż prowadzili oni akcje bojowe przeciwko II Rzeczpospolitej Polskiej przy czynnym wsparciu ludności białoruskiej czekającej na wyzwolenie spod „polskiego jarzma” (Panow, 2013). Między innymi w treści wymieniano następne czyny tych osób: „podpalenie nieruchomości osadnikom, panom i urzędnikom oraz prowadzenie ataków na policjantów" (Nowik, 2012). Podany fragment udowodnia, że białoruskie materiały edukacyjne gloryfikują postaci prowadzące działalność antypolską (która w tym przypadku nie może być odróżniona od działalności antypaństwowej). Podobne nastawienie w znacznej mierze jest skutkiem paradygmatu historycznego ujawnianego w materiałach szkolnych, który głosi, iż w okresie międzywojennym na ziemiach Białorusi Zachodniej trwała walka narodowowyzwoleńcza. Toczyła się ona o dołączenie kresów zamieszkanych przez Białorusinów do Białorusi Radzieckiej.

Jak zostało udowodnione powyżej, w tekstach opisujących II Rzeczpospolitą Polską nie brakuje wzmianek o Białorusinach, którzy opierali się państwu polskiemu (w tym z bronią w ręku), jak jest jednak z przekazem dziejów osób pochodzenia polskiego? Odpowiedzią na to pytanie będzie fakt, iż materiały dla uczniów nie zawierają nazwisk Polaków; opis dziejów bezpośrednich związanych z Polakami jako narodem odbywa się na zasadzie przekazu wiedzy w sposób bezosobowy, zaś w razie potrzeby, wspomnając o konkretnej personie, używa się określenia „Polak”. Dlatego też w powyższym tekście zaznaczono dążenie autorów do zacierania granicy między pojęciami „Polak” a „Polska”. Jedyny wyjątek od tej tendencji do rezygnacji ze wspominania o konkretnych postaciach stanowi Józef Piłsudski, bowiem nazwisko jego jest używane w materiałach szkolnych na masową skalę. Przykładowo w Historii Białorusi w latach 1917-1945 wspomniano o nim dziesięć razy. W pięciu przypadkach wspomnienie to mieści się w rozdziale opisującym historię pomiędzy rokiem 1917 a 1921, cztery razy w rozdziale o okresie międzywojennym i jeden raz w słowniku terminologii, znajdującym się na końcu książki. W Powszechnej Historii Najnowszego Czasu w latach 1918-1945 nazwisko Józefa Piłsudskiego zostało przywołano osiem razy, zaś w nieobowiązujących uczniów pozaszkolnych podręcznikach już o nim nie wspominano. W literaturze szkolnej Piłsudskiego prezentowano jako złodzieja, który winien był licznych zbrodni popełnionych na narodzie 
białoruskim, dusiciela wolności oraz człowieka niezdolnego do dotrzymywania obietnic. Podobne akcenty w opowiadaniu o dziejach Piłsudskiego wyglądają tym dziwniej, iż białoruscy historycy, opisując Lenina i Stalina, posługują się znacznie łagodniejszymi określeniami. W taki sposób z materiałów dla placówek oświaty usunięto wszystkie wzmianki o Polakach, wyjątkiem jest opis Naczelnika Państwa, który nie może być uznany za obiektywny, gdyż skupiano się jedynie na realnych i wymyślonych negatywnych cechach tej postaci historycznej. W podobnym podejściu nie ma niczego dziwnego, gdyż jest to kontynuacja powszechnej antypolskości, która zakorzeniła się w podręcznikach szkolnych.

\section{PODSUMOWANIE}

Celem powyższego artykułu jest analiza polityki historycznej (czyli kształtowania świadomości historycznej narodu z zamiarem realizacji określonych celów politycznych) państwa białoruskiego na podstawie ujawnienia treści szkolnych materiałów o II Rzeczypospolitej Polskiej. Niewątpliwie, jak każde państwo „młode”, Białoruś dąży do uzasadnienia własnej państwowości, znajdując korzenie w dziejach historycznych, jednak najbardziej istotne jest to, iż białoruska historiografia wywodzi obecną suwerenność z BSRR, jednocześnie podkreślając sprawiedliwość swoich granic oraz starannie likwidując z pamięci narodowej istotność roli Polaków w dziejach historycznych na Wschodzie. Podobna polityka dotyczy opisu okresu międzywojennego na Kresach, gdyż jest on w gruncie rzeczy propagandowy.

Podsumowując przeprowadzoną analizę materiałów, nasuwa się wniosek, iż ujawniony materiał (opisujący znajdowanie się obecnie zachodnich terenów Republiki Białorusi pod jurysdykcją II Rzeczypospolitej Polskiej) jest w istocie rzeczy nieprzychylny wobec Polaków oraz państwa polskiego. II Rzeczpospolita w ocenach piśmiennictwa naukowego dla białoruskich szkół jest synonimem państwa zła, porównywalnego do III Rzeszy. Autorzy szkolnej literatury przekonują uczniów, iż okres międzywojenny był czasem okupacji Białorusi Zachodniej przez Polaków; co więcej, literatura szkolna przekształca obraz stosunków pomiędzy Polską a Białorusią w stereotyp, że Polska i Polacy odgrywali w dziejach białoruskich rolę bez wyjątku negatywną (co zostało zauważone na przykładzie opisu lat międzywojennych). Jak wiadomo, znaczna część społeczeństwa białoruskiego składa się z osób pochodzenia polskiego zamieszkujących zachodnie obwody tejże republiki. Niewątpliwie przeprowadzana polityka 
historyczna jest skierowana przeciwko mniejszości polskiej, gdyż próbowano pozbawić ją tożsamości narodowej oraz poczucia narodowej godności, w ten sposób wzmacniając proces asymilacji.

Także na nieprzychylność polityki historycznej Białorusi do Polaków wskazuje kategoryczność tekstów literatury szkolnej, gdyż uwzględniają one tylko jedną opinię, stanowiącą kontynuację historycznej narracji Związku Radzieckiego. W badanych materiałach użyta jest terminologia będąca odzwierciedleniem aparatu kategoryjnego z okresu komunistycznego, który trudno uznać za przychylny Polakom czy Polsce. Po opracowaniu dostępnych źródeł można konstatować, iż polska problematyka w dzisiejszej Białorusi jest albo przemilczana, albo traktowana pobocznie. W przypadku wystąpienia pilnej potrzeby wspomnienia o narodzie polskim w białoruskich materiałach szkolnych na pierwsze miejsce wychodzi doktryna polityczna, która polega na oczernianiu obrazu polskiego. W literaturze uwypuklane są negatywne aspekty dziejów II Rzeczypospolitej. W celu stworzenia wizji Polski jako kata narodu białoruskiego w podręczniku dla klasy dziesiątej korzystano nawet $\mathrm{z}$ falsyfikowania faktologii. W wyniku prowadzonej narracji historycznej ujawniane w podręcznikach Białorusi tezy powinny być uznane za nienaukowe, co najmniej ze względu na brak uzasadnień ze strony białoruskich historyków. Podręcznikom białoruskim bowiem brakuje odniesienia do źródeł.

Jak już zostało wspomniane, do zakresu danego artykułu nie należy polemika z historykami piszącymi białoruskie podręczniki. Niemniej jednak historyczne narracje zawarte w podręcznikach białoruskich trudno uznać za odpowiadające zasadom naukowym, lecz propagandowym. Nie ulega wątpliwości, iż białoruscy uczniowie pobierają wiedzę o historii w wersji jak najbardziej antypolskiej, co stanowi kontynuację antypolskiej polityki historycznej.

\section{BibLIOGRAFIA:}

Koprowski, M. (2006). Białoruś - uparte trwanie polskości. Toruń: Wydawnictwo Adam Marszałek.

Kubiczek, F. (red.). (1994). Historia Polski w liczbach: ludność, terytorium. Warszawa: Zakład Wydawnictw Statystycznych.

Maresz, T. (2017). Podręcznik szkolny narzędziem kształtowania świadomości historycznej młodzieży. Analiza porównawcza polskich, rosyjskich, białoruskich i ukraińskich podręczników do historii z przełomu XX i XXI wieku. W: G. Gańko, M. Skotonicka-Palka, B. Techmański (red.), Młodzież w perspektywie edukacyjnej, społecznej, kulturowej (s. 123-136).Wrocław-Kraków. 
Nowak, A. (2011). Wstęp. Elegia o Kresach. W: J.Wieliczka-Szarkowa, Czarna księga Kresów. Kraków: Wydawnictwo AA.

Nowik, E.K. (2009). Istorija Biełarusi, XIX-naczało XXI w. Mińsk: izdatielskij centr BGU.

Nowik, E.K. (2012). Istorija Biełarusi 1917-1945 gg. Mińsk: Narodnaja Aswieta.

Panow, S.W. (2016). Istorija Biełarusi. 6-11 kłassy. Osnownyje daty i sobytija s kommientarijami. Mińsk: Awiersew.

Panow, S.W. (2017). Istorija Biełarusi. Posobije dla podgotowki k centralizowannomu tiestirowaniju. Mińsk: Awiersew.

Panow, S.W. (2013). Istorija Biełarusi. Osnownyje daty i sobytija s kommientarijami. Mińsk: Awiersew.

Panow, S.W. (2014). Istorija Biełarusi s driewniejszych wriemien do naczała XXI wieka $w$ woprosach i otwietach. 11 kłass. Mińsk: Awiersew.

Puryszewa, N.M., Starowojtowa, M.I. (2008). Istorija Biełarusi. Szkolnyj kurs w kratkom izłożenii. Mińsk: Тетралит.

Ratko, S.F. (2013). Istorija Biełarusi. Tiestowyj trienażer dla podgotowki k centralizirowannomu tiestirowaniju. Mińsk: Awiersew.

Sahanowicz, H. (2001). Historia Białorusi od czasów najdawniejszych do końca XVIII wieku. Lublin: Instytut Europy Środkowo-Wschodniej.

Śleszyński, W. (2013) Kresy Wschodnie, czyli Białoruś Zachodnia. Historia, współczesność, pamięć. Łomianki: Wydawnictwo LTW.

Staszkiwicz, N.S. (2014). Istorija Biełarusi. Posobije dla podgotowki k centralizirowannomutiestirowaniju. Mińsk: Awiersew.

Sowa, A.L. Brzoza, C. (2006). Historia Polski 1918-1945. Warszawa: Wydawnictwo Literackie

Szybieka, Z. (2002). Historia Białorusi 1795-2000. Lublin: Instytut Europy Środkowo-Wschodniej.

Treszczenko, J.I. (2009). Istorija Biełarusi (oktiabr’ 1917g. - naczało XXI w.). Mińsk: Adukacyi i wychawannia.

Winnicki, Z. (2002). Współczesna doktryna i historiografia białoruska (po roku 1989) wobec Polski i polskości. Wrocław: Oficyna Wydawnicza Arboretum.

Winnicki, Z. (2006). Historiografia jako metoda kształtowania współczesnej białoruskiej świadomości narodowej. Olsztyn: Wydawnictwo Uniwersytetu Warmińsko-Mazurskiego.

Uczebnyje programmy dlauczrieżdienij obszczego sriedniego obrazowanija s russkim jazykom obuczenija. Wsiemirnaja istorija.Istorija Biełarusi V-XI kłassy. Pobrane z: http://www.adu.by/ru/homepage/obrazovatelnyj-protsess/uchebnye-programmypo-uchebnym-predmetam-iii-iv-vii-ix-klassy-2012-god.html. 